\title{
Reflets
}

Revue ontaroise d'intervention sociale et communautaire

\section{Douglas Victor Janoff, Pink Blood - la violence homophobe au Canada, Les Éditions Triptyque, 2007. À paraître .}

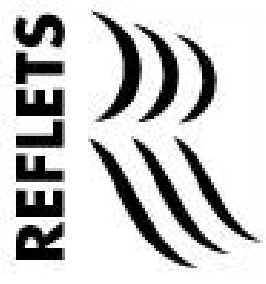

\section{Myriam Bals}

Volume 13, numéro 1, 2007

La violence dans tous ses états

URI : https://id.erudit.org/iderudit/016817ar

DOI : https://doi.org/10.7202/016817ar

Aller au sommaire du numéro

Éditeur(s)

Reflets : Revue ontaroise d'intervention sociale et communautaire

ISSN

1203-4576 (imprimé)

1712-8498 (numérique)

Découvrir la revue

Citer ce compte rendu

Bals, M. (2007). Compte rendu de [Douglas Victor Janoff, Pink Blood - la violence homophobe au Canada, Les Éditions Triptyque, 2007. À paraître .] Reflets, 13(1), 194-195. https://doi.org/10.7202/016817ar

Tous droits réservés (C) Reflets : Revue ontaroise d'intervention sociale et communautaire, 2007
Ce document est protégé par la loi sur le droit d'auteur. L'utilisation des services d'Érudit (y compris la reproduction) est assujettie à sa politique d'utilisation que vous pouvez consulter en ligne.

https://apropos.erudit.org/fr/usagers/politique-dutilisation/ 


\section{Pink Blood - la violence homophobe au Canada}

Janoff, Douglas Victor, qui paraîtra cet automne chez Triptyque.

par Myriam Bals,

Professeure agrégée, Université Laurentienne

Décapant, lucide, dérangeant, fort bien documenté, vous ne pourrez pas rester insensible à cet ouvrage qui lève le voile sur une réalité que nous ne connaissons que peu ou pas du tout : les crimes haineux contre les homosexuels. Douglas Victor Janoff a travaillé à partir d'archives de journaux et de tribunaux, les épluchant une par une, pour mieux comprendre ce qui s'est passé et découvrir trop souvent à quel point ces cas ont été traités à la légère non seulement par le système policier et judiciaire, mais aussi par divers groupes gais qui n'y voyaient pas non plus de crimes haineux, jouant ainsi le jeu d'une homophobie systémique. Rendons à César ce qui lui appartient! C'est ce que fait Janoff! Il désigne les responsables, dénonce les injustices et les lâchetés qui permettent que de tels crimes ne fassent pas toujours la une, à cause d'interprétations erronées. Il renvoie chacun de nous à notre conscience et à notre inconscience. Puissante, sa démonstration d'une sorte de violence organisée contre les homosexuels ne peut que nous toucher et nous dire que chacun de nous doit reconnaitre le problème de ces crimes découlant d'une homophobie aveugle qui fait encore des blessés et des morts dans les rangs des personnes ayant une sexualité différente.

L'auteur démontre avec force et de nombreux exemples que le système judiciaire ne punit pas, ou peu, les criminels qui s'attaquent à ces personnes différentes, indiquant par là même la complicité du système et de la société à laquelle nous appartenons. Comme quoi, nous avons tous une responsabilité, celle de laisser se perpétrer ces 
crimes ou, au contraire, celle d'y mettre fin en les faisant reconnaître et en espérant que dans un avenir proche les policiers et les tribunaux, sous la pression sociale, alourdiront les peines, tout comme ils l'ont fait par rapport à la violence faite aux femmes. À lire absolument par tous ceux et celles qui croient aux droits humains. 